\title{
STATUS OF THE GEOLOGICAL RESEARCH IN SVALBARD AND THE BARENTS SEA
}

\author{
TORE GJELSVIK; ANDERS ELVERHØI; AUDUN HJELLE; ØRNULF LAURITZEN \\ and OTTO SALVIGSEN
}

\begin{abstract}
GJELSVIK, TORE; ELVERHØI, ANDERS; HJELLE, AUDUN; LAURITZEN, ØRNULF and SALVIGSEN, OTTO, 1986: Status of the geological research in Svalbard and the Barents Sea. Bull Geol. Soc. Finland 58, Part 1, 131-147.

For more than one hundred years the archipelago of Svalbard has been visited by numerous geologists particularly interested in the stratigraphy and palaeontology of the nearly continuous series of late Palaeozoic, Mesozoic and Cenozoic sedimentary successions. After the second world war more detailed and process-oriented studies have greatly increased our knowledge of the stratigraphical, structural and petrological development of the crystalline basement, as well as of the palaeogeography, structure and depositional regime of the sedimentary basins. Dating of raised beaches and studies of erratics, striation and geomorphology have revealed more of the glacial history during the late Pleistocene and the Holocene.

Marine geophysical and geological research during the last 10-15 years has proved the existence of a thick sedimentary sequence covering the whole western Barents Sea shelf. Models of the stratigraphical and structural evolution have been developed but are still waiting for geological well control. The thickness, composition, and glacial history of the bottom sediments have been regionally explored.
\end{abstract}

Key words: Svalbard archipelago, western Barents Sea, geological history, stratigraphy, structural geology, glacial history, Precambrian-Holocene.

Tore Gjelsvik; Anders Elverhøi; Audun Hjelle; Ørnulf Lauritzen and Otto Salvigsen: Norsk Polarinstitutt, Rolfstangveien 12, 1330 Oslo Lufthavn, Norway.

\section{Introduction}

The archipelago of Svalbard is a unique area for research in historical geology since it consists of an almost continuous series of units, with an abundance of fossils, spanning in time from the Precambrian to the Cenozoic. Consequently, for the past hundred years or more geologists from many nations have studied the area.

Review and references of the pre World War II studies were given by Orvin (1940) in the eminent paper: "Outline of the geological history of Spitsbergen", one of the first geological studies to be based to a large extent upon remote sensing.

In the 1960s a renewed interest for the geology of Svalbard was triggered by the search for petroleum by international oil companies, and by Svalbard's special location with relation to plate tectonic models, it being a link between the North American and Eurasian plates. Since Svalbard is an elevated part of the submerged 
continental shelf of the Barents Sea, the northward advance of the offshore activity in the last few years has caused a new influx of geologists. The result has been a great increase in the number of geoscientific expeditions to Svalbard and its surrounding seas.

The geological information presented here has been collected from a great number of foreign and Norwegian papers published during the last $20-30$ years. In this short paper we can list only a few of the main works, which, on the other hand, contain references to the most important data sources.

The Norwegian Polar Research Institute (Norsk Polarinstitutt) is a state agency responsible for mapping and scientific research, including geology, in the Norwegian Arctic and Antarctic territories. For more details on the general geology of the Svalbard archipelago the reader is referred to the recently concluded series of geological maps of Svalbard in the scale of 1 : 500,000 (Norsk Polarinstitutt Skrifter No. 154 $A-D)$.

\section{Pre-Devonian rocks}

The main deformations in Svalbard are preDevonian. Intensive folding, thrusting and metamorphism occurred. The latest main orogeny is of Caledonian age. Granitic intrusions accompanied the orogeny and postdate the tectogenesis. The pre-Devonian rocks of Svalbard are located in three main areas (Fig. 1):

1. Northeast Spitsbergen,

2. Central and northern Nordaustlandet,

3. Prins Karls Forland and a narrow zone along the west coast of Spitsbergen.

\section{Northeast Spitsbergen and Nordaustlandet}

The pre-Devonian metamorphic complex in Svalbard is most completely developed in NE Spitsbergen, where a nearly continuous sequence of $19 \mathrm{~km}$ from Upper Riphean to Lower Ordovician is exposed (Harland 1959).
The type locality at Heclahuken has given name to this Hecla Hoek sequence as well as to metamorphic «basement rocks» elsewhere in Svalbard. As the depositional facies along the west coast of Spitsbergen often differ from those in NE Spitsbergen, and are frequently interrupted by unconformities, some geologists prefer to use the name Hecla Hoek only for NE Spitsbergen supracrustal rocks. These have been divided into three supergroups.

The lower, the Stubendorff-breen Supergroup $(11000 \mathrm{~m}+)$, consists in its lower part to a great extent of basic igneous rocks and feldspathic schists. The upper part contains mainly pelitic rocks with occasional acid meta-pyroclastics. The Lomfjorden Supergroup (c. $6000 \mathrm{~m}$ ), in the middle, is mainly detrital in the lower and carbonaceous in the upper part. The upper Hinlopenstretet Supergroup (c. $2000 \mathrm{~m}$ ), consists of Vendian tillite at the base, followed by limestone and shale containing a Cambrian and Ordovician fauna deposited under shallow marine and platform conditions. Recent palaeontological investigations have demonstrated an inter-provincial mixing of species of both American and European aspects. Middle and Upper Cambrian fossils are not recorded. This may indicate either a depositional break or deposition of nonfossiliferous strata.

Coarse-grained porphyritic granite with $\mathrm{K} / \mathrm{Ar}$ dates from c. 405 to c. $420 \mathrm{Ma}$. intrudes the rocks mentioned above (Gayer et al. 1966).

Geological investigations in Nordaustlandet began as early as in the first part of the 19th century, and other expeditions added new information in this century. Since 1965, Norsk Polarinstitutt has extended the detailed investigations from NW Nordaustlandet (Kulling 1934) into the central and northern parts (Flood et al. 1969; Ohta 1982; Lauritzen and Ohta 1984).

The supracrustal rocks of NW Nordaustlandet show similarities to NE Spitsbergen rocks. Although the strata are thinning eastwards, fossil evidence and lithology correspond closely to that of the Hinlopenstretet Supergroup of NE Spits- 


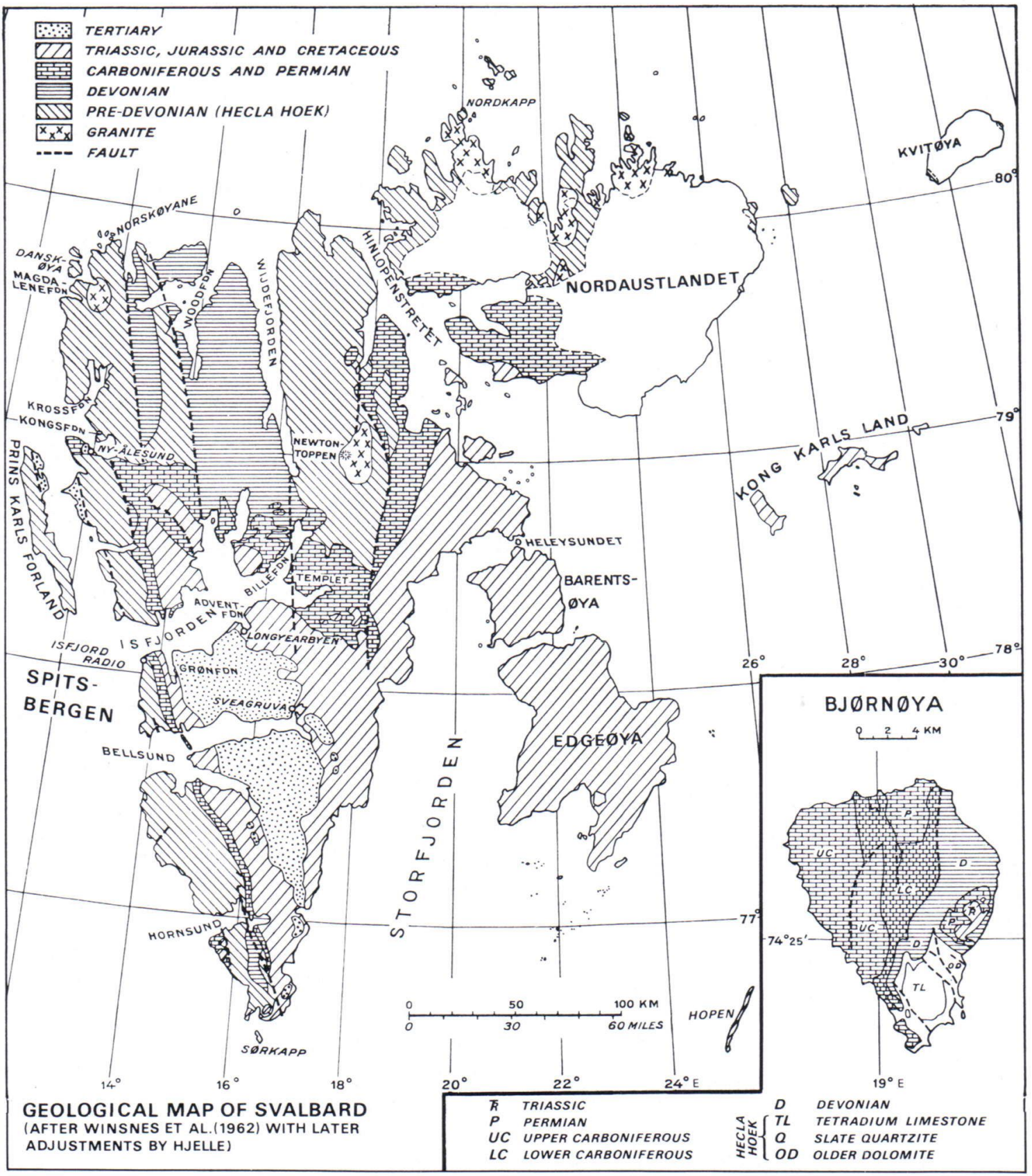

Fig. 1. Geological map of Svalbard.

bergen. No Middle or Upper Cambrian fossils are recorded. A Rb/Sr age of c. $520 \mathrm{Ma}$. from this area indicates a metamorphic episode which might explain the stratigraphic hiatus. The Mur- chisonfjorden Supergroup, below the Vendian tillite of NW Nordaustlandet corresponds roughly to the Lomfjorden Supergroup of NE Spitsbergen. 
In the lower part of the sequence the contact to igneous and metamorphic rocks is problematic, and metamorphic supracrustals occurring in the latter are tentatively correlated to the lower part of the successions known. Extrusive and sheet-like intrusive metadiabases and rhyolites occupy larger areas than previously thought. A Soviet $\mathrm{Rb} / \mathrm{Sr}$ age of $766 \mathrm{Ma}$. is reported from quartz porphyry.

Caledonian granites cut the supracrustal rocks on the north coast. Coarse, weakly foliated granites, in part of Rapakivi type occurring together with migmatitic rocks, are possibly rejuvenated basement rocks. K/Ar datings of both types of granite gave ages from c. 380 to c. $420 \mathrm{Ma}$.

From aerial photographs, Sandford (1956) postulated a major N-S fault zone at the northern coast of Nordaustlandet dividing this area into a western Hecla Hoek domain and an eastern area of mainly gneissic rocks belonging to the metamorphic complex of the Barents shield. Later investigations have not confirmed his assumptions.

\section{West Spitsbergen}

A relatively narrow zone of metamorphic preDevonian rocks is found along the west coast of Spitsbergen. The major fold structures are of Caledonian origin, but the meridional distribution of the rocks are obviously a result of the N-S trending Tertiary diastrophism connected with plate movements during the opening of the Greenland Sea.

Characteristic of the area from Hornsund to Kongsfjorden are thick flyschoid and conglomeratic sequences with volcanic horizons below, within and above the tillite horizons. The rocks are intersected by younger faults which occasionally have preserved wedges of younger platform sediments.

In the area around and to the south of Hornsund the upper part of the succession contains fossiliferous Lower Cambrian and Lower Ordovician beds overlying a phyllitic sequence which is tentatively correlated to the tillites of NE Spitsbergen (Major and Winsnes 1955; Birkenmajer 1960). The lower part of the succession contains an amphibolite complex with small-scale granitization phenomena. It has been suggested that the major part of the amphibolites are Precambrian basalt flows, which later in part underwent Caledonian granitization.

Relatively much work has been done in the area from Bellsund to Kongsfjorden in later years (Winsnes ed. 1979). The many pieces of information obtained indicate that the various provinces of Precambrian/early Palaeozoic supracrustal rocks along the coast, although distorted by Tertiary folding and faulting and subject to lateral variations, are closely related. Thus, there is general agreement on the upper part of the succession, which contains prominent key horizons like the Vendian tillite and underlying characteristic carbonate deposits.

In the Bellsund area the most prominent unit is the tillite at the mouth of the fjord. The clasts are mainly of calcareous and quartzitic composition, and the sedimentary structures indicate a partly fluvial origin. An assumed drop-tillite occurs south of the mouth of Isfjorden. PreVendian iron-bearing calcareous strata occur both immediately south and north of Bellsund, and have been correlated to similar deposits at Prins Karls Forland.

In a small area on the west coast north of Isfjorden, Upper Ordovician strata overlies glaucophane schists and eclogitic rocks unconformably. The relatively high pressure indicated by the composition of the these rocks is in contrast with the intermediate pressure conditions of other metamorphic rocks in Svalbard. This could imply an orogenic event at the earlier stage of the geosynclinal development. Radiometric dating is planned to trace an eventual older orogeny in this high-pressure area. Eclogite rocks are also found in NW Spitsbergen, east of Raudfjorden.

The supracrustal rocks around Kongsfjorden and northwards from Kongsfjorden have on lithological evidence been correlated to the 
Stubendorff-breen Supergroup of NE Spitsbergen. The rocks continue northwards into migmatite as zones of relics and as xenoliths. This is the only major area of gneissic and migmatitic rocks in Spitsbergen (Hjelle and Ohta 1974).

A major question is the cause of the lithologic and depositional differences between the preDevonian rocks of NE Spitsbergen and those along the west coast of Spitsbergen. The stratigraphy is in many respects similar to that of NE Spitsbergen and Nordaustlandet. Significant characteristics of the west coast rocks are the presence of late Riphean volcanics and the frequent breaks of the succession indicated by conglomerates, some of which evidently related to orogenic movements. Two main hypotheses have been proposed:

a) Both areas are part of a wide geosynclinal belt. Differences may have developed due to different positions in a main geosyncline or by separation into sub-zones by geanticlines.

b) The different provinces were widely separated in pre-Devonian time, and brought together in late Devonian by major transcurrent faults with lateral movements up to $1000 \mathrm{~km}$, so as to relate the eastern pre-Devonian sequence to that of central east Greenland, and the postDevonian to that of the Canadian Arctic. One of the suggested transcurrent faults went through the Billefjorden Fault Zone of central Spitsbergen (Harland et al. 1974). Recent investigations indicate that only minor lateral movements have taken place along the Billefjorden Fault Zone.

Another major problem relates to the question of a lower Precambrian basement. Based on assumed sedimentation rates, the age of the oldest metasupracrustal rocks in NE Spitsbergen is estimated to c. $1000 \mathrm{Ma}$. and a basement must be older. Intense and extensive metamorphism which is reflected in $\mathrm{K} / \mathrm{Ar}$ ages ranging from 450 to $360 \mathrm{Ma}$. seems to have overprinted earlier crystallization events. Based on metamorphic discontinuities in the migmatite area north of Kongsfjorden, the presence of Pre-Riphean basement rocks has been postulated from this area. However, undisputable basement outcrops have not yet been found. A granitic tillite boulder from Vendian tillite in Nordaustlandet, gave a $\mathrm{Rb} / \mathrm{Sr}$ isochrone age of $1275 \mathrm{Ma}$. This indicates a pre Upper Riphean igneous event.

At present the available radiometric datings of pre-Devonian rocks in Svalbard are too few and geographically too scattered to sort out preCaledonian orogenic/plutonic events. One of the main future tasks must therefore be to carry out systematic and reliable dating of the metamorphic rocks.

\section{Late Palaeozoic, Mesozoic and Tertiary successions}

\section{Late Palaeozoic}

The late Silurian and Devonian succession (Old Red Sandstone) of conglomerates, sandstone and shales, has a total composite thickness of 8000 $\mathrm{m}$. These sedimentary rocks which contain fish and plant fossils and were deposited in fresh or brackish water, accumulated after the main Caledonian folding and metamorphism. Manifestations of effusive rocks in the lower part of this succession have been reported recently (Murasov et al. 1983). The deposits were subjected to folding and faulting in an early phase, presumably late Silurian (Gee and Moody-Stuart 1966), and a late Devonian phase, the Svalbardian (Vogt 1928). These rocks are mainly preserved in a graben in central parts of northern Spitsbergen (Fig. 1). A stratigraphical scheme based on major studies is presented by Hjelle and Lauritzen (1982).

The late Palaeozoic and Mesozoic successions occur in an asymmetric basin in the southern parts of Spitsbergen, and the eastern islands (Fig. 1). Lying unconformably on the "Old Red Sandstones» or on the Hecla Hoek basement, the postCaledonian strata are found, a succession well described by Steel and Worsley (1984) (see Fig. 


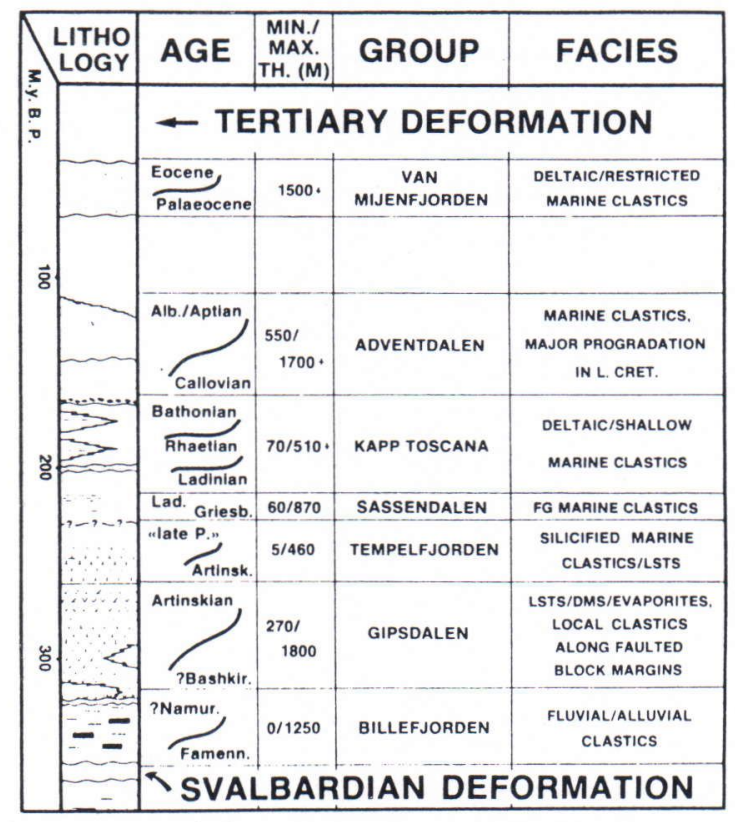

Fig. 2. A schematical stratigraphical scheme showing the general development of the post-Devonian groups of central Spitsbergen (from Steel and Worsley 1984).

2). A thick succession of non-marine, coal-bearing strata is found in the lowermost part, earlier referred to as the "Kulm» (Culm), now called the Billefjorden Group. This succession is best known from the area around Billefjorden, where numerous Cambridge University expeditions have worked (see Harland et al. 1976). The Middle Carboniferous units give evidence of transition to semi-arid climates and a general rise in sealevel. Rapid subsidence and faulting along major tectonic lineaments occurred, and deposition of red alluvial fan sequences with laterally equivalent fan delta deposits, evaporites and carbonates took place. These and other possible palaeoclimatic indicators within the Devonian and post-Caledonian successions are shown in Fig. 3 as interpreted by Steel and Worsley (1984). Troughs were filled in, and finally, in the late Carboniferous, a carbonate platform sequence developed, also directly upon Devonian or Hecla Hoek units in previously positive areas. This carbonate unit subsequently shows a regressive trend through the early periods of the Permian, until again in the late Permian a large-scale transgression took place. The sharp contrast between the carbonate dominated Gipsdalen Group with evaporites locally developed in its upper parts, and the overlying cherty strata of the Tempelfjorden Group, is found throughout Svalbard, and represents one of the best stratigraphical marker horizons. The stratigraphy is well documented by Cutbill and Challinor (1965), and Harland et al. (1974) calculated the thickness of the Carboniferous and Permian beds along the Billefjorden Fault Zone to $2300 \mathrm{~m}$.

\section{Mesozoic}

A generally stable platform environment is characteristic for the Mesozoic development of Svalbard. There is little evidence of active faulting during this period, except in the late Jurassic - early Cretaceous, when volcanic activity is manifested by basaltic intrusions and flows, the latter only in the eastern parts of the archipelago.

The lowermost group of the Triassic, the Sassendalen Group, consists of marine shales with some siltstones and sandstones. There are variations in thickness, reflecting reactivation of earlier lineaments; a maximum thickness of 700 $\mathrm{m}$ is found in the St. Jonsfjorden trough. The overlying Kapp Toscana Group represents two broadly regressive sequences, with sedimentational patterns reflecting important changes in depositional regimes.

The Adventdalen Group of Jurassic and lower Cretaceous comprises three superimposed formational units with a total thickness of $1800 \mathrm{~m}$. Open marine shales form the lowermost $800 \mathrm{~m}$ of the group, overlain by a $150 \mathrm{~m}$ thick deltaic sandstone unit and a $850 \mathrm{~m}$ thick mixed marine sequence. After the deposition of these sediments, a period of uplift, erosion and nondeposition took place, and particularly in the northern areas, erosion cut deep into the underlying strata. 


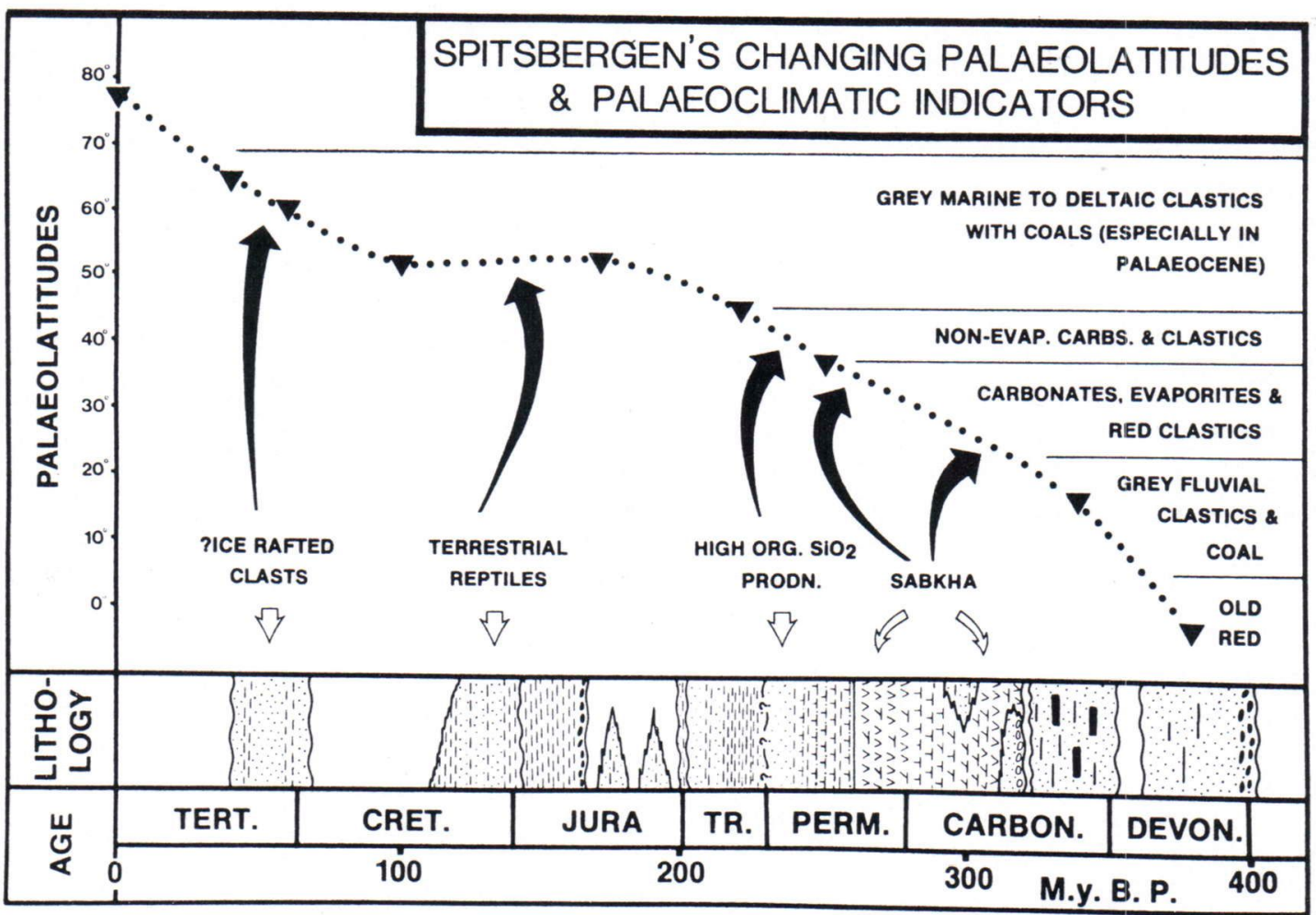

Fig. 3. Possible palaeolatitudes and palaeoclimatic indicators in relation to the major lithofacies observed (from Steel and Worsley 1984).

\section{Tertiary}

The Tertiary basin of Svalbard, stretching in a SE direction in central south Spitsbergen, developed during considerable tectonic upheaval, and therefore stands in great contrast to the relatively quiet Mesozoic conditions. The succession in Svalbard, comprising sandstones and shales with coal beds near the base, is generally accepted as being of Palaeocene - Eocene age. The thickness of the Tertiary sequence in the Central Basin are about $1500 \mathrm{~m}$ in the northeast and $2500 \mathrm{~m}$ in the southwest, reflecting a mainly Palaeocene basin asymmetry towards the sheared margin. According to vitrinite reflectance data, the original thickness of the Palaeogene strata was about $1500 \mathrm{~m}$ thicker than today (Manum and Throndsen 1978).

A narrow, intensely folded and faulted zone along the contact to the western crystalline basement was formed when Svalbard slid south-eastwards along the Spitsbergen Fracture Zone from a place north of Greenland during a transtensional phase of the plate tectonic movements, which led to the opening of the Greenland Sea. Basaltic volcanism occurred at about the same time on the north coast of Spitsbergen in response to the opening of the Eurasian Arctic Basin.

\section{Quaternary}

The Quaternary history in Svalbard is mainly a glacial history, and much of the research has focused on the extension and time of the last glaciation there. The different opinions on this area have probably been more diverging than on any other comparable region; extensive investi- 
gations during the last decade, however, have revealed much new information about the unconsolidated sediments in Svalbard and cleared up many questions (Boulton 1979; Troitsky et al. 1979; Salvigsen 1981; Salvigsen and Österholm 1982; Miller 1982; Elverhøi and Solheim 1983).

\section{Raised beaches}

The Holocene emergence pattern has been an important aid for the reconstruction of the last glaciation in Svalbard, and hundreds of radiocarbon dates on driftwood, whale bones, and shells from raised beaches have been presented.
The Holocene emergence for most parts of the archipelago is therefore now fairly well known (Fig. 4). Large quantities of pumice have drifted ashore several times during the Holocene; the about 6500 years old main pumice level has especially made it possible to draw isobases for raised beaches of this age.

The maximum Holocene emergence, of more than 100 m, is found in Kong Karls Land in the eastern part of Svalbard (Salvigsen 1981). On the other hand, Bjørnøya and the northwest corner of Spitsbergen had no Holocene emergence at all. The emergence pattern logically leads to a hypothesis suggesting a Late Weichselian glaciation centred over the eastern part of the archipelago

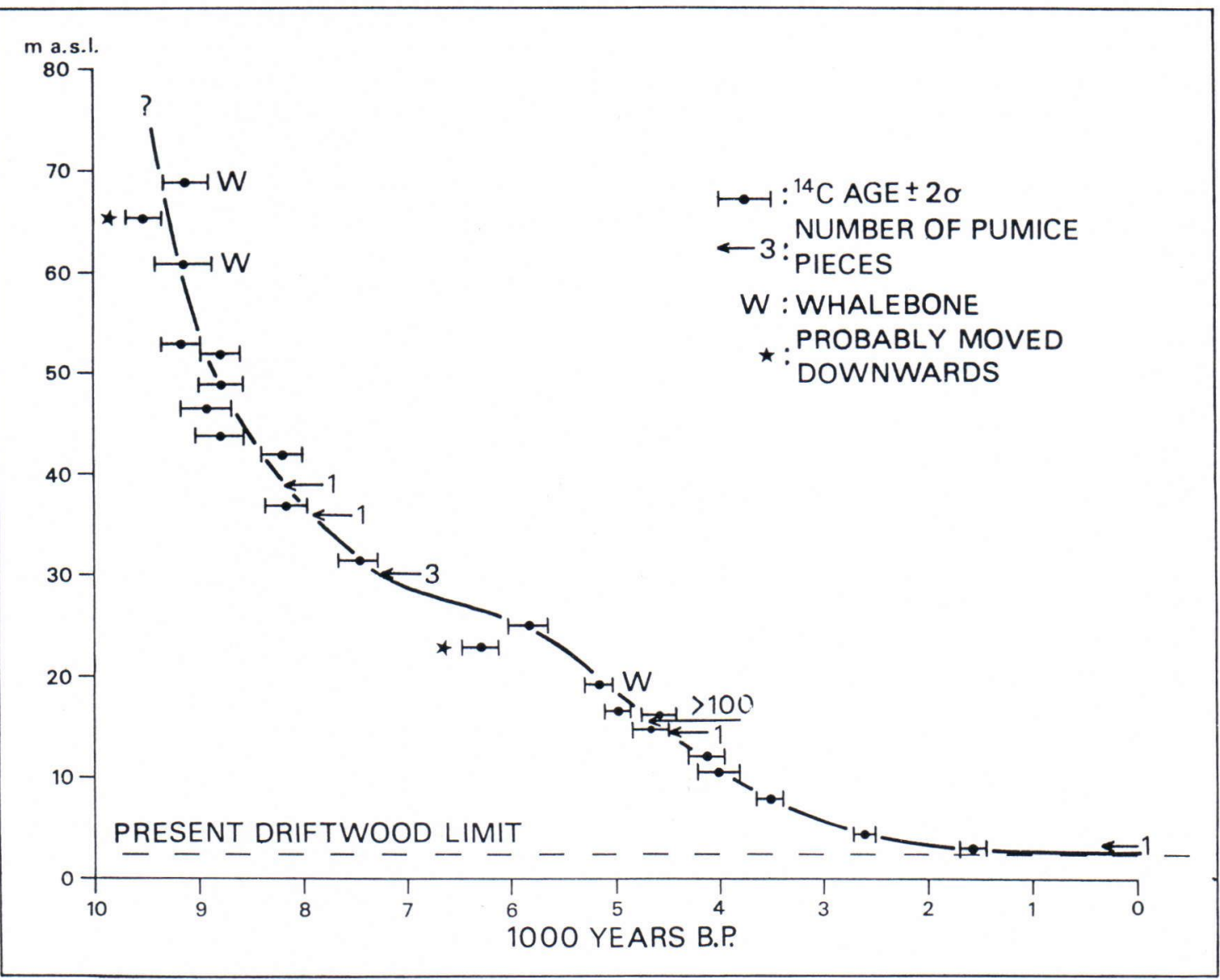

Fig. 4. Shoreline displacement curve for Svartknausflya, southern Nordaustlandet, mainly based on driftwood dates. 
and the adjacent Barents Sea. This is also compatible with the distribution of unconsolidated sediments in the western Barents Sea (see page 144 this paper).

Studies in the western and northern parts of Svalbard show at least one older generation of raised beaches above the series of Holocene beaches. The Late Weichselian glaciation here was limited and local, and large areas have been ice free for more than 40,000 years. This part of Svalbard has usually a series of raised beaches up to about 11,000 years old, followed by beaches of more than 40,000 years (Salvigsen and Österholm 1982). Mapping and absolute dating of these old beaches will be an important task in the future. But further studies of the Holocene beaches and more knowledge about Holocene marine limits and transgressions, especially in the southern part of Spitsbergen, are also required.

\section{Glacial history}

Studies of glacial erratics and geomorphology show that the whole area of Svalbard was completely covered by an extensive ice sheet at least once during the Pleistocene. As stated above no such glaciation took place in the Late Weichselian. The exact extension of the Late Weichselian glaciation is still unknown in many areas, but it was smaller than a previous glaciation. Due to insufficient dating methods it is still unknown whether the most extensive glaciation took place in the Early Weichselian or the Saalian. However, new dating techniques used on the many finds of pre Late Weichselian sediments have extended our knowledge about the Quaternary in Svalbard considerably. Investigations by $\mathrm{Th} / \mathrm{U}$ and amino acid analyses, and thermoluminiscence of sections exposing several glacial episodes separated by marine sedimentation, have yielded many age determinations of several hundred thousand years, some even up to one million years (Miller 1982). Calibration of the analytical methods, especially the amino acid one, has not yet been possible, and all chronologies for sediments older than the Late Weichselian in Svalbard are floating.

\section{Environmental geology}

Studies of processes in the active layer and other permafrost studies are also important in a high arctic area like Svalbard. Permafrost related research has been carried out at the Polish scientific station in Hornsund, a Norwegian microclimatic station is established in the Svea Mine, and an American permafrost project is under way in the Kongsfjorden area.

No special maps of the Quaternary geology of Svalbard have been published by the Norwegian Polar Research Institute. However, the geological maps in scale 1 : 100,000 include some Quaternary information. Maps of geomorphology and Quaternary geology in larger scales have been published by foreign universities, for example parts of southern Spitsbergen by Polish scientists. Cooperation projects on Quaternary mapping and research in central Spitsbergen have recently been initiated by university groups in Oslo and Bergen and the Norwegian Polar Research Institute.

Investigations of the surficial geology are of importance for various ecological studies. The arctic fauna is in many cases dependent on vegetation which is highly influenced by geomorphological processes. For instance a too intensive winter grazing of reindeer in Svalbard may destroy the vegetation and lead to serious soil erosion. This problem is now being studied under a multi-disciplinary project near Longyearbyen.

Petroleum exploration in the Barents Sea leads to an increasing demand for environmental data from the shore zone in Svalbard. Classification and mapping of shore types have therefore started based on air photo studies followed by field control. For this purpose the shores of western Spitsbergen were recorded on video tape from a helicopter in 1984. 


\section{Subsurface geology of the western Barents Sea and the continental margin}

\section{History of exploration}

Scientific exploration of the western Barents Sea and its continental margin by modern geophysical methods was initiated by the Lamont Doherty Geological Observatory in 1969, and followed by Norwegian, German and French expeditions in the early 1970s. At the same time, the Norwegian Geological Survey carried out a systematic aeromagnetic investigation of the southern part, and, since 1975, the Norwegian Petroleum Directorate has undertaken a regional geophysical grid survey of multichannel reflection seismies and gravimetry. Also French and German institutes have made geophysical surveying of high quality in the Barents Sea and over the margin. In this way, the southern part of the area has been covered by a rather dense grid; the northern part has not been covered that well, and some seismic profiles are of poor quality.

From 1975 to 1979, the Seismological Observatory of the University of Bergen conducted a systematic seismic survey of the margin all the way from Norway to the northern coast of Spitsbergen. Investigation of the margin has also been done by a number of geophysical vessels studying the sea floor spreading in the Norwegian and Greenland seas.

Exploration drilling for commercial purposes has recently started in the offshore area of Troms in the south-west corner of the Barents Sea and off the Murmansk coast.

\section{Sediment distribution and structural development}

As early as in 1977 Eldholm and Talwani (1977) demonstrated that the whole region north of a narrow strip of crystalline basement along the Norwegian coast was underlain by a thick sedimentary sequence which could be divided in three areas of different structure: (1) a wide, E-W oriented basinal province from Norway up to Bjørnøya, containing a thick sedimentary sequence; (2) the Svalbard Platform in the northwest with a thinner sequence; and (3) a narrow wedge of clastic sediments along the continental margin. Based on geomagnetic and unspecified seismic data, Soviet scientists (Krasil'šcikov et al. 1978) subdivided the crystalline basement of the western Barents Sea into two Baikalian orogenic zones trending NW-SE, separated by a Caledonian belt striking NE-SW. The platform cover was subdivided in two complexes, a lower comprising late Riphean to Devonian rocks, and an upper consisting of three stages from Carboniferous to Cenozoic time. Geologists of the Norwegian Petroleum Directorate have described the stratigraphy and structural development of the western Barents Sea in a series of papers since 1979 (Rønnevik and Jacobsen 1984). Because of inferior data, the northern part could not be considered in detail. In the southern part, however, a number of regional reflectors were distinguished and used for stratigraphic correlations. They also identified a NE-SW trending system of basins and ridges, faults and diapiric provinces. A French-Norwegian group, utilizing their own new geophysical data as well as other available information, recently published a detailed treatise on the evolution of the sediment sequence of the western Barents Sea (Faleide et al. 1984). Most of the following summary is extracted from this paper.

The basinal province in the south shows different development on either side of a line between Nordkapp and Bjørnøya (Fig. 5). The western part, with a late Palaeozoic to Cenozoic sequence which has been tilted to the west and subjected to rifting, consists of ridges and basins trending NNE-SSW. Salt diapirs are mainly found in the Tromsø Basin. On the east side is an epeirogenetic, intracratonic basin, elongated NE-SW, containing large diapirs in the central Nordkapp Basin. The salt has pierced more than $8 \mathrm{~km}$ of sediments, originally deposited perhaps in late Devonian. The Svalbard Platform is cov- 


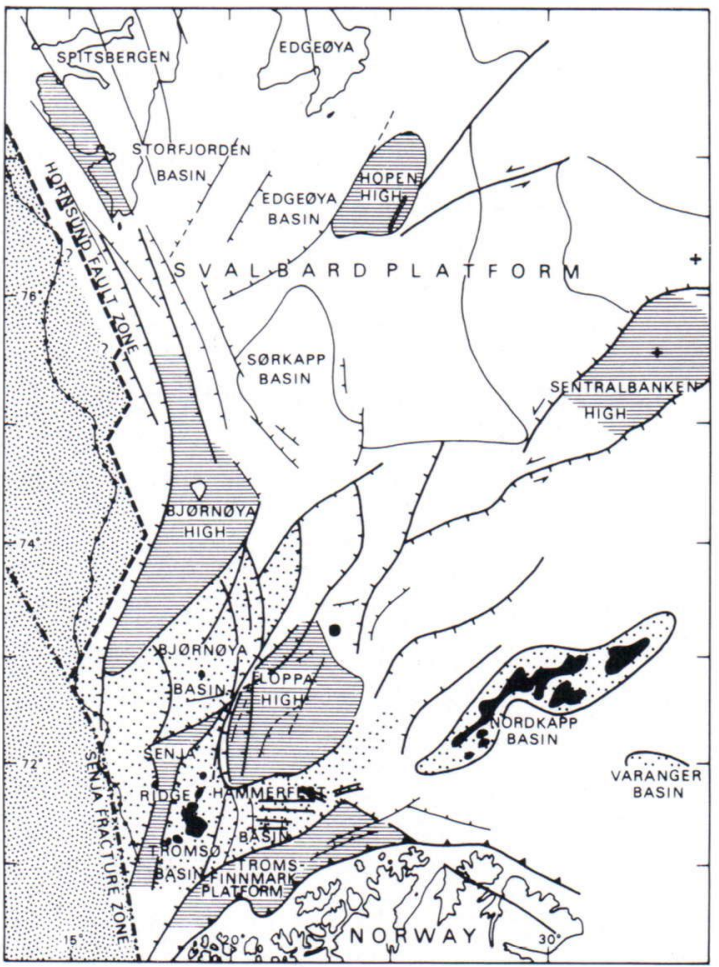

W FAULTS

OOCEANIC BASEMENT $\hookrightarrow$ SHELF EDGE

. SALT DIAPIRS

- basement outcro

Fig. 5. Regional structural map of the western Barents Sea. Modified after Faleide et al. 1984, Fig. 9.

ered by thick, relatively flatlying late Palaeozoic and Triassic sediments. It is characterized by shallow depths to stratigraphic levels and possibly basement, and the sequences have relatively high acoustic velocities. A system of highs and basins is found also on the platform, but has not yet been fully delineated. The central part consists of two highs and an intervening basin. It appears that the tectonical regime was rather uniform all over Svalbard and the western Barents Sea during late Palaeozoic, early and mid Mesozoic time. SW-NE trending faults formed during mid Jurassic to early Cretaceous appear both on the platform and the basinal province, but have been most active in the latter giving rise to its present structural elements. In late Jurassic - early Cretaceous the basinal province subsided in re- lation to the Svalbard Platform. This subsidence continued in late Cretaceous and early Palaeozoic when parts of Svalbard and the Svalbard Platform remained elevated.

According to Eldholm et al. (1984) the western margin of the Barents Sea may be divided in three parts: from $70^{\circ}$ to $73^{\circ} \mathrm{N}$ it consists of a rifted zone of basins and ridges belonging to the basinal province. The observed strata thicken to the west, reflecting a continuous subsidence of the margin from lower Cretaceous to Oligocene. The margin from $73^{\circ}$ to $76^{\circ} \mathrm{N}$, west of the Svalbard Platform, consists of a N-S striking ridge segment presumably of crystalline basement, and a prograding wedge of Palaeogene-Neogene sediments, thinner than south of $73^{\circ} \mathrm{N}$. The margin off Spitsbergen is separated in two elements by a marked fault system: the Hornsund Fault Zone, paralleling the coast line, and the Graben structures of the west coast of Spitsbergen. The sequence of the landward side is not well known due to a scarcity of reflectors, but the geophysical signature is reported to be similar to that of the Svalbard Platform. On the west side of the fault zone a sedimentary basin, up to $7 \mathrm{~km}$ thick and prograding westward in the upper part, stretches to the Knipowich Ridge. It has been suggested that the whole sequence was deposited in front of the Hornsund Fault Zone in mid-Oligocene in responce to the elevation of Spitsbergen in late Tertiary.

The northern, often ice covered margin of Spitsbergen has a limited data coverage, and only very tentative interpretations have been offered (Sundvor and Eldholm 1979). The eastern part is underlain by $2 \mathrm{~km}$ thick low velocity layers, presumably of Tertiary age. The western part, including the $800 \mathrm{~m}$ deep Yermak Plateau, has a thinner cover of low velocity sediments over a smooth opaque acoustic basement. In analogy with the Vøring Plateau off the Lofoten islands this acoustic basement has been suggested to consist of Tertiary basalts. A hotspot under the Yermak Plateau has also been proposed.

It should be noted that the interpretation of 
the stratigraphy of the western Barents shelf and its margin is based on geophysical data with very limited geological control. Differences of opinion exist among various authors on the timing of some of the main reflectors. Collection of geological well data alone can settle this dispute.

\section{Shallow geophysical and geological studies in the western Barents Sea}

\section{Background}

The Barents Sea is an epicontinental sea at the northwestern part of the Eurasian continental shelf, with an average depth of $230 \mathrm{~m}$. Its shallowest and deepest parts are found at the western margin, with $20 \mathrm{~m}$ and $500 \mathrm{~m}$ depths, respectively.

The Barents Sea has most likely been glaciated several times during the Quaternary, and today its northern parts are supplied with sediments from grounded, calving glaciers. The area is therefore a unique laboratory for studies of Quaternary stratigraphy in polar regions and of glaciomarine sedimentation. For the northern and central parts, only a thin $(5-10 \mathrm{~m})$ veneer of sediments overlies the Mesozoic bedrock, leading to a close cooperation of Quaternary geology studies and investigations of the bedrock.

Norwegian investigations in the Barents Sea are limited to the last fifteen years. Soviet's research in the area has a longer history. Klenova (1960) published the comprehensive volume "The Geology of the Barents Sea», based on studies of more than 2000 shallow sediment samples.

During the Norwegian surveys more than 600 shallow $(<3 \mathrm{~m}$ ) surface sediment samples and $30,000 \mathrm{~km}$ of shallow seismic profiles have been collected. The Norwegian Polar Research Institute and the Petroleum Directorate have carried out the major part of the surveys, and the data have formed the base for more than 40 publications. All available data are now to be compiled in a thematical map series: The Physical Environment, western Barents Sea, in the scale of $1: 1,500,000$, published by the Norwegian Polar
Research Institute. The maps include data on surface sediment distribution, sediment thickness, bathymetry, gravity and bed rock geology. This map series, also including information on sea ice distribution and ocean currents, will be completed in the near future.

\section{Surface sediments and bedrock geology}

In the first Norwegian survey shallow sampling and shallow geophysical recordings were carried out on Spitsbergenbanken, in the northwestern part of the Barents Sea (Fig. 6). The data were studied by various groups in Norway, focusing on the relationship between the surface sediments and the underlying bedrock. Dating and mineralogical/geochemical investigations showed well defined stratigraphical and lithological provinces in the surface sediments, which due to the thin ( $<5 \mathrm{~m}$ ) sediment cover strongly indicated a close relationship between sediments and bedrock. The use of surface sediments to identify the underlying bedrock has also been applied to the northern Barents Sea, where shallow seismic records indicate $<10 \mathrm{~m}$ sediments. According to the surface sediments, gradually older rocks are found from Sentralbanken and northwards to Kvitøya (Fig. 7).

The difficulties of relating surface sediments to the bedrock are partly due to the glaciomarine origin of the sediments. Only limited investigations on this type of sediments have so far been carried out with respect to source or provenance. Ongoing research of glaciomarine sedimentation in front of glaciers calving into the sea around Svalbard, has shown that the major part of the sediment supply is deposited within a distance of less than $10-15 \mathrm{~km}$ from the ice front. Thus the rapid deposition of the glaciomarine sediments show that also these deposits, like till, can be applied to outline the main trend of the underlying bedrock. To some extent the bedrock geology has been tested by shallow drilling $(<5$ $\mathrm{m}$ ) showing similar lithologies in the bedrock as those found in pebbles and gravels in the surface sediments. 
Sediment distribution and glaciation history

The extension of a Barents Sea ice sheet represents an outstanding problem in the reconstruction of former glaciations on the northern hemisphere. Up to 1980 the discussion was hampered by limited and also inadequate data. Surveys in recent years have provided a much better database for interpretation of the Quaternary history (Elverhøi and Solheim 1983; Solheim and Kristoffersen 1984).

In water depths shallower than $300 \mathrm{~m}$, the Quaternary sediments consist of a sequence of till overlain by glaciomarine deposits, and covered by Holocene mud. The total thickness is commonly less than $10 \mathrm{~m}$, and no hiatuses have so far been observed. Datable material from the glacigenic sediments has not yet been obtained, but the apparently continuous sequence of till and glaciomarine sediments grading into Holocene postglacial sediments, strongly suggests a Late Weichselian ice cover in northern and central parts of the Barents Sea. Such an interpretation is also in accordance with the datings of raised beaches in Svalbard, which clearly indicate a Late Weichselian ice cover over at least the northern Barents Sea (Salvigsen 1981). A probable outline of the Late Weichselian maximum extension has been drawn from till ridges and

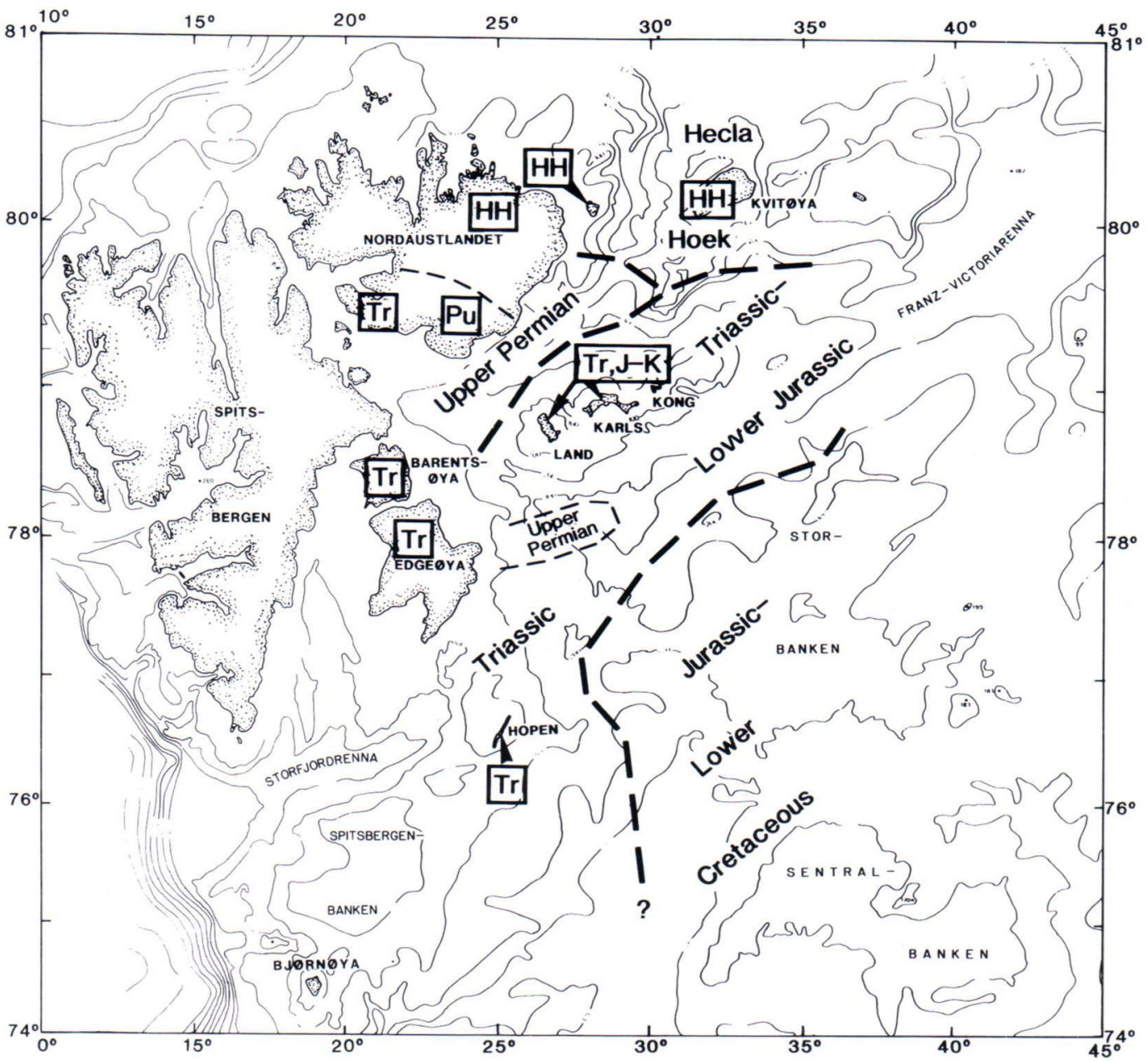

Fig. 6. Bathymetric map showing features related to former ice margins in the western and northern Barents Sea. 


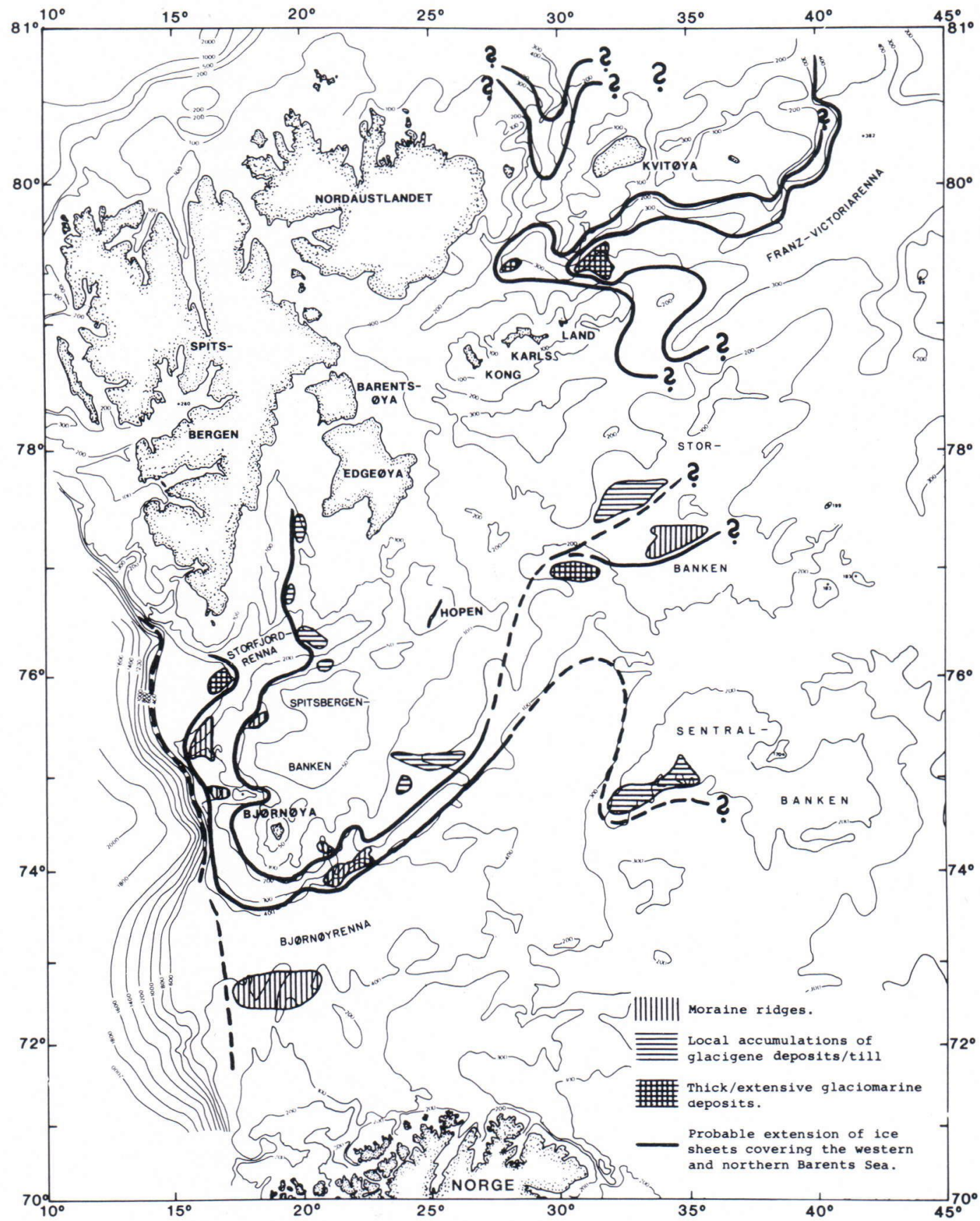

Fig. 7. Map showing stratigraphical provinces for the Quaternary sediments, which are suggested to reflect the underlying bedrock. Onland geology in adjacent areas is indicated in squares. 
thick glaciomarine sediments at a water depth of about $300 \mathrm{~m}$ (Fig. 7). At this water depth there is also an increase in sediment thickness, especially in the glaciomarine sediments, from $2-3$ $\mathrm{m}$ to $20 \mathrm{~m}$.

Towards the margins the sediment thickness increases gradually, from $50 \mathrm{~m}$ in central parts of Bjørnøyrenna to $>400 \mathrm{~m}$ above bedrock at the shelf edge (Solheim and Kristoffersen 1984). In these sediments four major unconformities are identified, and interpreted to reflect at least four major glacial expansions to the shelf edge. No datings are available, but relative sedimentation rates suggest that the youngest major expansion occurred more than 100,000 years BP, probably in Early Weichselian. A full-scale expansion of ice to the shelf edge in the western Barents Sea probably reflects a coalescence of the Svalbard and Scandinavian ice masses, while a minor expansion as suggested for the Late Weichselian would have left Bjørnøyrenna as an open calving bay.

\section{Aspects of modern sedimentation}

The modern Barents Sea spans a range of sedimentary environments, from glaciomarine in the north to year-round ice-free conditions in the south. For central and southern parts, the sediments are reworked on shallower parts and redeposited in deeper basins at a rate of $3-5 \mathrm{~cm} /$ 1000 year. In the northern parts sediments are partly supplied from glaciers and also from sea ice. The depositional rate is of a similar magnitude as that found in non-glaciated areas. On the shallow (20-40 m) Spitsbergenbanken strong currents prevail, and the sea floor sediments are dominated by coarser material which mainly consists of molluscs and barnacles.

The carbonate deposits are of Holocene age, directly overlying the Late Weichselian glacigenic deposits. Similar sequences of glacigenic and carbonate sediments are also common in ancient deposits, especially late Precambrian sediments, where this facies association has been used as an evidence against a glacial origin of the clastic sediments. Carbonates are in general related to warm-water deposition. However, the deposits on Spitsbergenbanken demonstrate that carbonates may form in polar regions under suitable conditions. On Spitsbergenbanken the formation is related to the glacioeustatic sea level rise leaving the area starved of clastic supply, combined with upwelling of Atlantic water rich in nutrients (Bjørlykke et al. 1978).

So far the investigations in the Barents Sea have been general research with a main emphasis on studies of the Quaternary geology. Future work will, however, be strongly influenced by the hydrocarbon exploration, which gradually moves northwards. The geological knowledge of the area is still limited, and practical questions asked by both government and industry, can mostly be answered through more basic research.

\section{Economic geology}

Coal mining has been going on for 70 years in Spitsbergen. Extensive coal measures occur in several horizons from Devonian to Tertiary, but are mostly either too thin or too impure for economic use. Most mines (Longyearbyen, Barentsburg, Svea) are extracting gas-rich coal of Tertiary age. The Pyramiden mine is producing Carboniferous coal. Total production amounts to one million tons a year.

A dozen wells drilled for petroleum exploration since 1960 have yielded no oil and only small quantities of gas. The western Barents Sea was opened for commercial exploration a few years ago in the south-western corner, off the coast of Troms, Northern Norway. Gas in quite large amounts has been found in several wells, sometimes with traces of oil, but the first oil strike took place only in the autumn of 1984 .

Industrial minerals of different kinds (i.e. limestone, marble, anhydrite/gypsum) are found in large amounts in some places, but are located too far away from consumers. In the sedimentary 
succession of Svalbard, beds of phosphorite, iron and uranium have been found, but so far in too small quantities for commercial exploration. The same can be said for showings of lead, zink, copper, iron and asbestos minerals in metamorphic rocks. However, the exploration for mineral

\section{References}

Birkenmajer, K., 1960. Relation of the Cambrian to the PreCambrian in Hornsund, Vestspitsbergen. Int. Geol. Congr. XXI Sess. Part XIII.

Bjørlykke, K.; Bue, B. \& Elverhøi, A., 1978. Quaternary sediments in the northwestern part of the Barents Sea and their relation to the underlying Mesozoic bedrock. Sedimentology 25, 227-246.

Boulton, G. S., 1979. Glacial history of the Spitsbergen archipelago and the problem of a Barents shelf ice sheet. Boreas $8,31-57$.

Cutbill, J. L. \& Challinor, A., 1965. Revision of the stratigraphical scheme for the Carboniferous and Permian of Spitsbergen and Bjørnøya. Geol. Mag. 102, 418-439.

Eldholm, O. \& Talwani, M., 1977. Sediment distribution and structural framework of the Barents Sea. Geol. Soc. Am. Bull. 88, 1015-1029.

-; Sundvor, E.; Myhre, A. M. \& Faleide, J. I., 1984. Genozoic evolution of the continental margin off Norway and western Svalbard. In Spencer, A. M. et al. (eds.): Petroleum geology of the north European margin. Norwegian Petroleum Society.

Elverhøi, A. \& Solheim, A., 1983. The Barents Sea ice sheet, a sedimentological discussion. Polar Research 1 n.s., $23-42$.

Faleide, I. F.; Gudlaugsson, S. T. \& Jacquart, G., 1984. Evolution of the western Barents Sea. Marine and petroleum Geology 1, 123-148. Buttworth \& Co. Ltd.

Flood, B.; Gee, D. G.; Hjelle, A.; Siggerud, T. \& Winsnes, T. S., 1969. The geology of Nordaustlandet, northern and central parts. Nor. Polarinst. Skr. 146. 139.

Gayer, R. A.; Gee, D. G.; Harland, W. B.; Miller, J. A.; Spall, H. R.; Wallis, R. H. \& Winsnes, T. S., 1966. Radiometric age determination on rocks from Spitsbergen. Nor. Polarinst. Skr. 137. 39 p.

Gee, D. G. \& Moody-Stuart, M., 1966. The base of the old red sandstone in central north Haakon VII Land, Vestspitsbergen. Nor. Polarinst. Årbok 1964, 57-68.

Harland, W. B., 1959. The Caledonian sequence in $\mathrm{Ny}-$ Friesland, Spitsbergen. Quart. J. Geol. Soc. Lond. 114, $307-342$.

—; Cutbill, J. L.; Friend, P. F.; Gobbett, D. J.; Holliday, D. W.; Maton, P. I.; Parker, J. R. \& Wallis, R. H., 1974. deposits in Svalbard is in an initial stage only, due to high costs of investigation and even higher for production and transportation.

Acknowledgement. We are indebted to Mrs. A. Brekke for correcting the English language and for assistance in preparing the manuscript for publication.

The Billefjorden Fault Zone, Spitsbergen. Nor. Polarinst. Skr. 161 .

-; Pickton, C. A. G.; Wright, N. J. R.; Croxton, C. A.; Smith, D. G.; Cutbill, J. L. \& Henderson, W. S., 1976. Some coal-bearing strata of Svalbard. Nor. Polarinst. Skr. 164. 89 p.

Hjelle, A. \& Lauritzen, Ø., 1982. Geological map Svalbard 1 : 500,000, Sheet 3G Spitsbergen Northern Part. Nor. Polarinst. Skr. $154 \mathrm{C}$.

- \& Ohta, Y., 1974. Contribution to the geology of north western Spitsbergen. Nor. Polarinst. Skr. 158. 107 p.

Klenova, M. V., 1960. The geology of the Barents Sea (in Russian). Akad. Nauk. SSR, Moscow. 367 p.

Krasil'scikov, A. A.; Livsic, Ju. Ja. \& Sokolov, V. N., 1978. Problem of the structure of the bottom of the Barents Sea (in Russian). Tectonics of Europe and of continuous areas, ancient platforms, Baikalides, Caledonides, Chapt. VIII, 399-405.

Kulling, O., 1934. Scientific results of the Swedish-Norwegian Arctic Expedition in the summer of 1931. Part XI. The Hecla Hoek Formation round Hinlopenstretet. Geogr. Ann. (4). Stockholm.

Lauritzen, Ø. \& Ohta, Y., 1984. Geological map Svalbard 1 : 500,000, Sheet 4G Nordaustlandet. Nor. Polarinst. Skr. 154 D.

Major, H. \& Winsnes, T. S., 1955. Cambrian and Ordovician fossils from Sørkapp Land, Spitsbergen. Nor. Polarinst. Skr. 106.

Manum, S. B. \& Throndsen, T., 1978. Rank of coal and dispersed organic matter and its geological bearing in the Spitsbergen Tertiary. Nor. Polarinst. Årbok 1977, 159-177.

Miller, G. H., 1982. Quaternary depositional episodes, western Spitsbergen, Norway: Aminostratigraphy and glacial history. Arctic and Alpine Research 14, 321-340.

Murasov, L. G.; Pcelina, T. M \& Semevskij, D. V., 1983. New data on evidence of volcanism in the Lower Devonian and Upper Triassic formations of West Spitsbergen (in Russian). Geologija Spicbergena, 109-135. Sevmorgeologija, Leningrad.

Ohta, Y., 1982. Hecla Hoek rocks in central and western Nordaustlandet. Nor. Polarinst. Skr. 178.

Orvin, A. K., 1940. Outline of the geological history of Spits- 
bergen. With geological map 1 : 1,000,000 (Second edition). Skr. om Svalbard og Ishavet $78.60 \mathrm{p}$.

Rønnevik, H. \& Jacobsen, H.-P., 1984. Structural highs and basins in the western Barents Sea. In Spencer, A. M. et al. (eds.): Petroleum geology of the north European margin, 19-32. Norwegian Petroleum Society.

Salvigsen, O., 1981. Radiocarbon dated raised beaches in Kong Karls Land, Svalbard, and their consequences for the glacial history of the Barents Sea area. Geogr. Ann. 63A, 283-291.

— \& Østerholm, H., 1982. Radiocarbon dated raised beaches and glacial history of the northern coast of Spitsbergen, Svalbad. Polar Research No. 1, 97-115.

Sandford, K. S., 1956. The stratigraphy and structure to a subjacent metamorphic complex in North-East Land (Spitsbergen). Q. Journ. Geol. Soc. Lond. 112, 339-362.

Solheim, A. \& Kristoffersen, Y., 1984. Physical environment Western Barents Sea, $1: 1,500,000$. Sediments above the upper regional unconformity: thickness, seismic stratig- raphy and outline of the glacial history. Nor. Polarinst. Skr. 179B. 26 p.

Steel, R. J. \& Worsley, D., 1984. Svalbard's post-Caledonian strata - an atlas of sedimentological patterns and palaeogeographic evolution. Pp. 109-135 in Spencer, A. M. et al. (eds.): Petroleum Geology of the North European Margin. Norwegian Petroleum Society.

Sundvor, E. \& Eldholm, O., 1979. The western and northern margin of Svalbard. Tectonophysics 59, 239-250. Elsevier Scientific Publishing Co.

Troitsky, L. S.; Punning, J.-M. K.; Hutt, G. \& Rajama, R., 1979. Pleistocene glaciation chronology of Spitsbergen. Boreas 8, 401-407.

Vogt, Th., 1928. Den norske fjellkjedes revolusjonshistorie. Norsk Geol. Tidsskr. 10 (1-2), 97-116. Oslo 1929.

Winsnes, T. S. (Ed.), 1979. The geological development of Svalbard during the Precambrian, Lower Palaeozoic and Devonian. (Symposium on Svalbard's geology, Oslo 2-5 June 1975. Nor. Polarinst. Skr. 167. 324 p. 